\title{
Effects of Strategy-Based Instruction on Low Proficiency Omani ESL Learners' Acquisition of Writing Skills
}

\author{
P. M. Binu ${ }^{1}$ \\ ${ }^{1}$ English Language Centre, The University of Technology and Applied Sciences- Al-Mussanah, Oman \\ Correspondence: P. M. Binu, English Language Centre, The University of Technology and Applied Sciences- \\ Al-Mussanah, Oman. ORCID id: https://orcid.org/0000-0001-6097-1026
}

Received: April 25, 2021

doi: 10.5539/elt.v14n6p36
Accepted: May 14, 2021

Online Published: May 17, 2021

\begin{abstract}
The past few decades have seen a great amount of second language acquisition research on language learning strategies. Most of the research on strategy instruction had more practical goals than mere theoretical understanding. These practical goals are different ways of equipping learners with self-learning strategies. The latest developments in education and research, especially with the incorporation of neurosciences, psychology, and information technology have provided promising solutions to most of the problems faced by the low proficiency learners in second language acquisition. They also have given birth to numerous learning tools and methods of instruction. As a result, teachers can now rely on various sources of information and communication technology and use individualized instructional strategies to provide adequate support to these struggling learners especially for enhancing their writing skills. However, they need to be careful in providing support because an excessive amount of support may hinder the learners' ability to work independently and develop critical thinking skills.
\end{abstract}

Keywords: low proficiency Omani ESL learners, self-efficacy, language learning strategies, strategy-based instruction, self-regulation, independent learning, writing skills

\section{Introduction}

The main goal of formal education and training is to enable students to become lifelong independent learners. Once learners acquire this potential, they will be able to gather new information and develop various skills. Educators, in general, are keen on making teacher-learner efforts more productive to enhance learner autonomy. But it becomes challenging when there are students with various learning difficulties. Without looking into their problems and taking appropriate remedial measures, a healthy teaching-learning environment may not prevail in a class. The normal classroom procedures are often inadequate to deal with the learning and behavioral problems of this marginalized group. Knowledge and understanding of their personal, behavioral, and learning problems are vital in enhancing second language acquisition and making them independent learners.

One of the challenges teachers face in the language class is how to deal with the heterogeneity of students. Without identifying the distinctive features that form the differences in the learners' schematic knowledge, areas of interest, learning styles and preferences, it is difficult to adopt appropriate instructional techniques and tailor the learning materials for inclusive education. Instructional methods depend on many factors that include the learners' background, level of language proficiency, learning goals, content, environment, the learning resources, etc. Using the same method of instruction will not be effective to cater to the learning demands of the diverse group. Hence, language teachers need to have a wide range of instructional techniques and tools to meet the instructional objectives. As Petrina (2007) rightly remarks, a single method cannot meet all our goals, nor can a single method accommodate all learning styles at once (p. 125). Harmer (2001) claims that students learn more quickly if the teaching methods used in the class match their preferred learning styles. Veettil (2016) suggests that the learning outcomes and pedagogical plans should be realistic and practical to make learners competent users of English in the modern world (p. 173).

As learning is an active, constructive process, students need to work actively and in purposeful ways to gather new information. They should also integrate this new information or ideas to what they already know. This act of intellectual processing of constructing meaning or creating something new is the basis of effective learning. However, this can be achieved only when learners have the capacity to work independently. 


\section{Literature Review}

The proponents of strategy-based instruction believe that students with strategic knowledge of language learning, compared with others who do not use any self-learning strategies, are very active and efficient, and they acquire language fast and easily. They further argue that such learners are more resourceful and flexible and can personalize the learning strategies to achieve the desired goals. As Macaro (2001) points out, "across learning contexts, those learners who are pro-active in their pursuit of language learning appear to learn best" (p. 264).

Self-regulation is manifest in the different aspects of learning such as goal setting, developing and using appropriate learning strategies, regulation and monitoring of tasks, management of resources, the reaction to external feedback, etc. As Pintrich and Zusho (2002) state, self-regulated learning is an active constructive process whereby learners set goals for their learning and monitor, regulate, and control their cognition, motivation, and behavior, guided and constrained by their goals and the contextual features of the environment ( $p$. 64). Self-regulated students are fully conscious of their strengths and weaknesses and when they face any obstacles in learning, they search for alternative strategies to overcome the learning difficulties.

The interdependence of motivation and learning is another feature of self-regulation. When learners feel motivated, they invest more time in learning and use various independent learning strategies. And if they are successful in employing self-regulated strategies, they become more motivated and energetic to proceed with the learning tasks (Zimmerman, 2000). Students with high motivational orientation will engage in more meta-cognitive activities, more cognitive strategy use, and better effort management. Schunk (1984) claims that self-regulated are self-motivated and resourceful and they have the capacity re-adjust a learning response to a new or changing condition.

According to Zimmerman (1990), self-regulated learning has three common features; forethought, performance and self-reflection. First, it entails planning and the use of appropriate learning strategies. Second, the -regulated learners self- monitor their performance, and the last feature is that all self-regulated learners have the capacity to think critically about the choice of a learning strategy or response. They can use appropriate strategies to meet their learning goals by analyzing and integrating self-generated and external feedback. A self-regulated learning process involves goal-directed activities that learners instigate, modify, and sustain (Zimmerman, 1989). Self-regulated learners pay careful attention to instruction, integrate knowledge, transfer information to new situations, and feel confident about their abilities in achieving the learning target (Schunk, 1989). Harris (1986) found that self-monitoring was a powerful intervention and it resulted in increased time on task and better academic performance.

To become successful learners, students need to constantly monitor their progress at different stages of learning, and it encompasses all the aspects of self-regulation. Zimmerman (2004) remarks that self-motivation, planning, goal setting, attention control, and the ability to adapt various learning strategies are essential to keep track of the independent learning process. Harris (1986) claims that self-monitoring is key to self-regulation. To be successful at self-regulation, learners should develop the ability to control attention. Harnishferger (1995) states that attention control needs constant self-monitoring. It means to clear the mind of all distractions and to choose an appropriate place for learning. Studies show that the academic standards of students improve when they stay focused on tasks. It has the potential to increase their learning skills and improve their course performance.

Effective self-regulated learning occurs when learners develop the capacity to engage in frequent self-evaluation. Bandura (1998) argues that student self-evaluation is an educative activity, and it makes them active participants in their education. Most self-regulated learners can set different targets in learning such as using multiple learning strategies, self-monitoring the learning process, seeking help from teachers and peers, and self-evaluating the progress in learning. Independent learners do not always try to do all the tasks themselves. On the other hand, they approach their peers for help and assistance (Butler, 1998). An important feature of self-regulation is seeking peer assistance. Self-regulated learners are good at using others as a source to overcome their difficulties in learning (Newman \& Schwager, 1995). However, most of the low proficiency learners, who are unmotivated, believe that if they approach for help, their peers will look down upon them. They have low self-esteem and do not take any risks in learning (Karabenick \& Knapp, 1991). Therefore, they are, in most situations, unwilling to approach their peers for help. They often hesitate to adopt independent learning strategies or express any interest in collaborative learning. In the words of Al- Mahrooqi (2012), "Active discouragement comes from linguistically incompetent peers who mock their friends' efforts to use their English outside the classroom. Unmotivated themselves, they are poor models for their friends" (p. 267).

An essential component of self- regulation is critical thinking. As Fisher (2005) points out, "The most important resource any society has are the intellectual resources of its people. A successful society will be a thinking society 
in which the capacities for lifelong learning of its citizens are most fully realized" (p. 8). Critical thinking enables students to analyze and restructure self-generated actions. It is self-directed, self-monitored, and self-corrective.

\section{Language Learning Strategies}

Self-regulated learners can adopt a range of strategies and improvise them to accomplish their goals. Grenfell and Harris (1999) claim that a successful language learner is one who takes a timely decision regarding the use of appropriate strategy to enhance learning in the given context. Chamot and El-Dinary (1999) go further, proposing that good learners would consistently monitor and improvise strategies. At the same time, poor learners would continue with ineffective strategies. Therefore, language teachers should guide students in using appropriate learning strategies. In the words of Binu (2016), “The role of language teachers doesn't end with the teaching of skills in the target language. They should also train their students to use various strategies to accelerate their learning process" (p. 140).

\section{Research Questions}

The current research aimed at answering the following questions:

1. Does strategy-based instruction have any differential effects on the writing skills of low proficiency learners?

2. Is there any relation between self-regulated learning strategies and students' motivation and self-efficacy?

\section{Research Methodology}

Since the main objective of this experimental study was to investigate the effectiveness of strategy-based instruction on enhancing writing skills in low proficiency learners, it employed a pre-test post-test quasi-experimental research design. The treatment was not limited to the low proficiency learners in the class. Instead, it was given to all students in the target group to uphold the ethical principles in research. The details of the students who were identified as low proficiency learners were never revealed to the class.

\subsection{Participants}

The participants consisted of 49 intermediate students from two sections of the General Foundation Program at the University of Technology and Applied Sciences, Al Mussanah, Oman. Section A, which consisted of 25 students was treated as the control group and section B, with 24 students was the target group. Besides, some model lessons were given to the target group by the researcher. The learners in the target group were trained in using various self-regulated learning strategies in planning, organizing, editing, and revising their short essays during the intervention. They were also given additional classroom tasks and home assignments.

To equate the control and treatment groups, a pre-test was administrated at the beginning of the experimental study. After the pre-test, the data generated were subjected to statistical analysis and the results showed that there was no significant difference between the pre-test scores of both the control group and the experimental group. It was followed by the application of intervention strategies to the experimental group. Two different patterns of treatment were applied during the experimental study. The control group was given the usual English language training in the class while the treatment group was given additional training to develop self-learning strategies. The experiment continued for three months. When the treatment was over, a post-test was administered to both groups.

\section{Data Analysis}

The result of the pre-test and the post-test is given in tables for a detailed analysis. For the interpretation of data, the means, standard deviations, and differences were calculated for each group. Significance of difference between the mean scores of both the control group and the treatment group on the variables of pre-test scores and post-test scores were tested at 0.05 level by applying t-test. To analyze the effects of treatment on high and low levels of achievement of the two groups, a statistical program, SPSS (20.0) was used. The result of the post-test showed significant differences between the control group and the treatment group. The target group, that received the treatment for about three months, showed substantial improvement in their writing standards. At the end of the treatment, a feedback questionnaire was given to all students in the treatment group and some students were interviewed at random. From test results and the feedback received from students, it was clear that self-regulated learning could make the learners more confident and efficient in language learning. In short, these findings support the predictions that self-regulated learners show greater improvement in academic achievement, study skills, motivation, and self-efficacy. As evident from the outcome of the research, self-directed learning strategies can raise the level of language proficiency as well as self-efficacy. The results of the pre-test and post-test scores are as follows: 


\section{Paired Sample T-Test}

The paired sample descriptive statistics show that there is no statistically significant difference between the scores of the pre-test and the post-test of students in the control group. As given in Table 1 the pre-test score is $(\mathrm{M}=5.06$, $\mathrm{SD}=1.22)$ and the post-test is $(\mathrm{M}=5.10, \mathrm{SD}=1.07)$. Therefore, there is no noticeable increase in achievement in the post-test.

Table 1. Paired sample statistics of the control group

\begin{tabular}{llllll}
\hline & & Mean & N & Std. Deviation & Std. Error Mean \\
\hline Pair 1 & Post-test & 5.1000 & 25 & 1.07977 & .16096 \\
& Pre-test & 5.0667 & 25 & 1.22289 & .18230
\end{tabular}

Table 2. Paired sample test of the control group

\begin{tabular}{|c|c|c|c|c|c|c|c|c|}
\hline & \multicolumn{5}{|c|}{ Paired Differences } & \multirow{3}{*}{\multicolumn{2}{|c|}{ t $\quad$ df }} & \multirow[t]{3}{*}{ Sig. (2-tailed) } \\
\hline & \multirow[t]{2}{*}{ Mean } & \multirow[t]{2}{*}{$\begin{array}{l}\text { Std. } \\
\text { Deviation }\end{array}$} & \multirow[t]{2}{*}{$\begin{array}{l}\text { Std. Error } \\
\text { Mean }\end{array}$} & \multicolumn{2}{|c|}{$\begin{array}{l}95 \% \text { Confidence Interval } \\
\text { of the Difference }\end{array}$} & & & \\
\hline & & & & Lower & Upper & & & \\
\hline $\begin{array}{l}\text { Post-test } \\
\text { Pre-test }\end{array}$ & .03333 & .52657 & .07850 & -.12486 & .19153 & .425 & 24 & .673 \\
\hline
\end{tabular}

Table 3. Paired sample statistics of the target group

\begin{tabular}{llllll}
\hline & & Mean & N & Std. Deviation & Std. Error Mean \\
\hline Pair 1 & Post-test & 5.6818 & 24 & 1.28086 & .19310 \\
& Pre-test & 4.8636 & 24 & 1.57511 & .23746 \\
\hline
\end{tabular}

Table 4. Paired sample test of the target group

\begin{tabular}{|c|c|c|c|c|c|c|c|}
\hline & \multicolumn{4}{|c|}{ Paired Differences } & \multirow{3}{*}{\multicolumn{2}{|c|}{ t df }} & \multirow[t]{3}{*}{ Sig. (2-tailed) } \\
\hline & Mean & Std. Deviation & $\begin{array}{l}\text { Std. } \\
\text { Error } \\
\text { Mean }\end{array}$ & $\begin{array}{l}95 \% \text { Confidence } \\
\text { Interval of the } \\
\text { Difference }\end{array}$ & & & \\
\hline & & & & Lower & & & \\
\hline $\begin{array}{l}\text { Post-test } \\
\text { Pre-test }\end{array}$ & .81818 & .86327 & .13014 & 1.08064 & 6.287 & 43 & .000 \\
\hline
\end{tabular}

\section{Independent Sample T-Test (between the groups)}

The group statistics (Table 5) and the test statistics (Table 6) clearly show that there isn't a statistically significant difference in the pre-test scores of both the target group and the control group. The target group has a mean score of 4.86 and the standard deviation is $1.57(\mathrm{M}=4.86, \mathrm{SD}=1.57)$. At the same time, the mean score of the control group is 5.06 and the standard deviation is $1.22(\mathrm{M}=5.06, \mathrm{SD}=1.22)$. From this data, it can be assumed that the there was no major difference between the participant groups in terms of their writing proficiency and it also justifies their selection for the current study.

Table 5. Group statistics: The target group and the control group

\begin{tabular}{llllll}
\hline & Class & N & Mean & Std. Deviation & Std. Error Mean \\
\hline Pre-test & $\mathrm{t}$ & 24 & 4.8636 & 1.57511 & .23746 \\
& $\mathrm{c}$ & 25 & 5.0667 & 1.22289 & .18230 \\
\hline
\end{tabular}


Table 6. Statistical analysis of the pre-test: The target group and the control group

\begin{tabular}{|c|c|c|c|c|c|c|c|c|c|}
\hline & \multirow[t]{2}{*}{$\mathbf{F}$} & \multirow[t]{2}{*}{ Sig. } & \multirow[t]{2}{*}{$\mathbf{t}$} & \multirow[t]{2}{*}{ df } & \multirow[t]{2}{*}{$\begin{array}{l}\text { Sig.(2-t } \\
\text { ailed) }\end{array}$} & \multirow[t]{2}{*}{$\begin{array}{l}\text { Mean } \\
\text { Difference }\end{array}$} & \multirow[t]{2}{*}{$\begin{array}{l}\text { Std. Error } \\
\text { Difference }\end{array}$} & \multicolumn{2}{|c|}{$\begin{array}{l}95 \% \text { Confidence } \\
\text { Interval of the } \\
\text { Difference }\end{array}$} \\
\hline & & & & & & & & Lower & Upper \\
\hline $\begin{array}{l}\text { Equal } \\
\text { variances } \\
\text { assumed }\end{array}$ & 2.713 & .103 & -.680 & 87 & .498 & -.20303 & .29852 & -.79637 & .39031 \\
\hline $\begin{array}{l}\text { Equal } \\
\text { variances } \\
\text { not } \\
\text { assumed }\end{array}$ & & & -.678 & 81.094 & .500 & -.20303 & .29936 & -.79866 & .39260 \\
\hline
\end{tabular}

The group statistics (Table 7) and the statistical analysis of the post-test (Table 8) illustrate that the target group obtained a substantially higher score $(\mathrm{M}=5.68, \mathrm{SD}=1.28)$ than the control group $(\mathrm{M}=5.10, \mathrm{SD}=1.07)$ in the post-test. Levene's Test for Equality of Variances revealed that the variability of the number of writing measures in the target group and the control group is the same $(\mathrm{P}=0.23, \mathrm{P}>.05)$. The statistical analysis (Table 8$)$ found a considerable difference in the post-test scores of both the target group and the control group.

Table 7. Group statistics: The target group and the control group

\begin{tabular}{llllll}
\hline class & & N & Mean & Std. Deviation & Std. Error Mean \\
\hline Post-test & t & 24 & 5.6818 & 1.28086 & .19310 \\
& c & 25 & 5.1000 & 1.07977 & .16096
\end{tabular}

Table 8. Statistical analysis of the post-test: The target group and the control group

\begin{tabular}{|c|c|c|c|c|c|c|c|c|c|}
\hline & \multirow[t]{2}{*}{$\mathbf{F}$} & \multirow[t]{2}{*}{ Sig. } & \multirow[t]{2}{*}{$\mathbf{t}$} & \multirow[t]{2}{*}{ df } & \multirow[t]{2}{*}{$\begin{array}{l}\text { Sig. } \\
\text { (2-tailed) }\end{array}$} & \multirow[t]{2}{*}{$\begin{array}{l}\text { Mean } \\
\text { Difference }\end{array}$} & \multirow[t]{2}{*}{$\begin{array}{l}\text { Std. Error } \\
\text { Difference }\end{array}$} & \multicolumn{2}{|c|}{$\begin{array}{l}95 \% \text { Confidence } \\
\text { Interval of the } \\
\text { Difference }\end{array}$} \\
\hline & & & & & & & & Lower & Upper \\
\hline $\begin{array}{l}\text { Equal } \\
\text { variances } \\
\text { assumed }\end{array}$ & 2.003 & .161 & 2.319 & 87 & .023 & .58182 & .25090 & .08312 & 1.08052 \\
\hline $\begin{array}{l}\text { Equal } \\
\text { variances not } \\
\text { assumed }\end{array}$ & & & 2.314 & 83.921 & .023 & .58182 & .25139 & .08190 & 1.08174 \\
\hline
\end{tabular}

\section{Discussion}

Based on the findings, this study recommends the need for a positive change in the attitude of teachers and institutions towards low achieving students. It suggests some effective ways of addressing their problems in English language classrooms. First, the interaction pattern in the language class should be student-centered to make them active participants by providing ample opportunities for engaging tasks. In addition to that, students should be involved in all aspects of the learning process, such as feedback, error correction, classroom discussion, decision making, etc. Furthermore, strategy instruction should be promoted in the language class to help students become independent in learning and discourage excessive teacher dependency. In short, these findings have implications for both classroom instruction and future research.

Some pedagogical implications for enhancing independent learning strategies are as follows: Language instructors should encourage learners to take responsibility for their learning. They need to accept learners' individual differences and motivate them to express themselves freely and fearlessly in the language classroom. Peer-assisted learning strategies should be encouraged in class because low-proficiency learners will be more comfortable with peers than their teacher to interact with, and such interactions and exchange of learning strategies will boost their confidence and self-efficacy. To facilitate self-regulated learning strategies, teachers should first change their role of being an authoritarian to a facilitator in class and re-define the traditional teaching practices. It is also important for them to think carefully about students' individual differences and needs while planning and preparing their lessons. In addition, they should tailor the learning materials and modify the instructional strategies 
to cater to the learning needs of the low achievers in their class. Before applying a new strategy in the classroom instruction, teachers should consider the learners' strengths, weaknesses, and preferences to maximize student engagement and learning.

\section{Strategy Instruction}

To make the second language learning process more student-centered, learners should be trained in using language learning strategies independently. First, they need to be introduced to a range of strategies for language learning. When the teacher facilitates effective use of strategy knowledge and raises their awareness of learning strategies, they become more conscious about their own learning process. To make this process simple, teachers should elicit the learners' schematic knowledge about strategies and then help them evaluate their current use of learning strategies. Also, they should assess the learners' beliefs about how language acquisition learning takes place; whether it occurs because of conscious action, good intelligence, chance, or the systematic use of appropriate learning strategies.

To help those students who do not use any learning strategies, teachers should explain and model effective strategies. Some learners, especially the low proficiency learners may find it difficult to employ new strategies. Therefore, while modeling in class, a few, effective strategies should be emphasized. Also, teachers should demonstrate their own use of strategies and make their thinking process louder in the class. This process of 'thinking loud' in the class will enable students to have a better idea about strategy use and how learning takes place. In short, when the teacher provides simple, concrete, visualized and personalized exemplifications of a learning strategy, the students will find the lesson more meaningful and achievable.

In addition to modeling some learning strategies, students should be given multiple opportunities to make autonomous use of their strategies and encouraged to share them with the rest of the class. This will be a good chance for students to compare their strategies with those of their peers. By doing so, it can be assured that all students become aware of the various strategies required for a task and they can also adopt some effective ones used by good learners. Also, they should be trained to transfer the strategies they use in one situation to a different context. At the same time, they should never be forced to use a strategy, but rather encouraged to choose one which they think is suitable for them.

In short, the focus of strategy training should be given to the learning problems the students are trying to solve. Unless they recognize the problems in learning and are confident to face them, strategy-based instruction cannot be very successful. Teachers should make all students; especially the proficiency learners feel that they are competent enough in acquiring language skills in English. This feeling of being competent or self-efficacy is the key to motivation and independent learning.

\section{Conclusion}

In summary, this study provides a clear understanding of the relation between self-regulated learning strategies and second language acquisition. A clear perception of how learning strategies contribute to language acquisition will guide teachers to reflect on their current instructional strategies and make necessary changes to cater to the demand of the new language learners' community. By modeling the use of new strategies in class and providing more scaffolding when students begin to use them, teachers can help the low proficiency learners become successful at self-regulation. In short, second language instruction should be largely student-centered, and teachers should attend to the learners' individual differences and learning styles. By encouraging students to use self-regulated learning strategies, teachers may enhance second language acquisition in low proficiency learners and therefore, further contribute to their intrinsic motivation to become independent lifelong learners.

\section{References}

Al-Mahrooqi, R. (2012). A student perspective on low English proficiency in Oman. International Education Studies, 5(6), 263-271. https://doi.org/10.5539/ies.v5n6p263

Bandura, A. (1998). Personal and collective efficacy in human adaptation and change. Advances in psychological science, 1, 51-71.

Butler, R. (1998). Determinants of help-seeking: Relations between perceived reasons for classroom help-avoidance and help-seeking behaviors in an experimental context. Journal of Educational Psychology, 90(4), 630-643. https://doi.org/10.1037/0022-0663.90.4.630

Chamot, A. U., \& P. B. El-Dinary. (1999). Children are learning strategies in language immersion classroom. Modern Language Journal, 83(3), 319-338. https://doi.org/10.1111/0026-7902.00025

Fisher, R. (2005). Teaching Thinking (2nd ed.). New York: Continuum. 
Grenfell, M., \& Harris. (1999). Modern Language and Learning Strategies: In Theory and Practice. London: Rout ledge.

Harmer, J. (2001). A human, cultural, and linguistic disaster? Modern English Teacher, 10(3), 5-10.

Harnishferger, K. K. (1995). The development of cognitive inhibition: Theories, definitions, research. In F. N. Dempster \& C. J. Brainerd (Eds.), Inference and Inhibition in Cognition (pp. 176-206). San Diego: Academic Press.

Harris, K. R. (1986). Self-monitoring of attentional behavior vs. self-monitoring of productivity: Effects on-task behavior and academic response rate among learning disabled children. Journal of Applied Behavior Analysis, 19, 417-423. https://doi.org/10.1901/jaba.1986.19-417

Karabenick, S. A., \& Knapp, J. R. (1991). Relationship of academic help-seeking to the use of learning strategies and other achievement behavior in college students. Journal of Educational Psychology, 83, 221-230. https://doi.org/10.1037/0022-0663.83.2.221

Macaro, E. (2001). Learning strategies in foreign and second language classrooms. London: Continuum.

Newman, R. S., \& Schwager, M. T. (1995). Students' help-seeking during problem-solving: Effects of grade, goal, and prior achievement. American Educational Research Journal, 32, 352-376. https://doi.org/10.3102/00028312032002352

P. M., Binu. (2016). Self-regulation: Strategies for Lifelong Independent Learning. In P. Mishra, B. Mishra \& K. Patil (Eds.), Vital Issues in English Language Teaching: Papers in Honour of Professor Z. N. Patil (pp. 132-141). Jaipur: YKing Books.

Petrina, S. (2007). Instructional Methods and Learning Styles. Curriculum and Instruction for Technology Teachers, 125-152. https://doi.org/10.4018/978-1-59904-337-1.ch004

Pintrich, P. R., \& Zusho, A. (2002). The development of academic self-regulation: The role of cognitive and motivational factors. In A. Wigfield \& Eccles (Eds.), Development of achievement motivation (pp. 249-284). San Diego, CA: Academic Press. https://doi.org/10.1016/B978-012750053-9/50012-7

Schunk, D. H. (1984). The self-efficacy perspective on achievement behavior. Educational Psychologist, 19, 199-218. https://doi.org/10.1080/00461528409529281

Schunk, D. H. (1989). Models of self-regulated learning and academic achievement. In B. J. Zimmerman \& D. H. Schunk (Eds.), Self- regulated learning and academic achievement: Theory, research, and practice (pp. 83-110). New York: Springer-Verlag. https://doi.org/10.1007/978-1-4612-3618-4_4

Veettil, R. P. (2016). Changing Paradigms in English Language Teaching. Kannur: Kairali Books.

Zimmerman, B. J. (1989). Models of self-regulated learning and academic achievement. In B. J. Zimmerman \& D. H. Schunk (Eds.), Self- regulated learning and academic achievement: Theory, research, and practice (pp. 1-25). New York: Springer-Verlag. https://doi.org/10.1007/978-1-4612-3618-4

Zimmerman, B. J. (1990). Self-regulated learning and academic achievement: An overview. Educational Psychologist, 25(1), 3-17. https://doi.org/10.1207/s15326985ep2501_2

Zimmerman, B. J. (2000). Self-efficacy: An essential motive to learn. Contemporary Educational Psychology, 25, 82-91. https://doi.org/10.1006/ceps.1999.1016

Zimmerman, B. J. (2004). Socio-cultural influence and students' development of academic self-regulation: A social cognitive perspective. In. D. M. Mcinerney \& S. Van Etten (Eds.), Big theories revisited (pp. 139-164). Greenwich, CT: Information Age.

\section{Copyrights}

Copyright for this article is retained by the author(s), with first publication rights granted to the journal.

This is an open-access article distributed under the terms and conditions of the Creative Commons Attribution license (http://creativecommons.org/licenses/by/4.0/). 